INDUSTRY-SPECIFIC EFFECT OF CSR INITIATIVES:

HOTELS AND AIRLINES

Ana B. Casado

Juan L. Nicolau

Felipe Ruiz

Ricardo Sellers

Dept. of Marketing

Faculty of Economics

University of Alicante

PO Box 99

03080 Alicante

SPAIN 


\title{
INDUSTRY-SPECIFIC EFFECT OF CSR INITIATIVES: HOTELS AND AIRLINES
}

\begin{abstract}
Purpose - This study examines the relationships between a firm's CSR activities and its performance and risk. We hypothesize that industry-level effects are highly determinant of the sign and magnitude of these relationships to establish a ranking of industries to identify the position of the most prominent tourism-related industries: hotels and airlines. Based on the cybernetic model of decision making and the heuristics thereof, shareholders base their investment decisions derived from CSR announcements on the idea that the industries behave differently; their fixed costs being a relevant factor.
\end{abstract}

Design/methodology/approach - We estimate the industry-specific effects of CSR initiatives on firms' performance and risk using a sample of 583 announcements from the Spanish Stock Market.

Findings - The results show that while CSR announcements have a positive effect on performance when we do not account for industry specific factors, once we incorporate these factors into our analysis, we find that firm performance and risk vary quite substantially as a function of the industry to which the firm belongs. Interestingly, while the hotel industry presents an average behavior (standing at 9th position in returns, 15th in terms of risk, and 8th according to the ratio returns/volatility), the airline industry presents the worst situation of all industries: last in performance and last in risk.

Practical implications - The results help managers assess their decisions and allocate CSR resources optimally.

Originality/value - This article is the first attempt to empirically test and comprehensively detect the different relationship between CSR and firm performance across industries.

Keywords: corporate social responsibility; cybernetic model of decision making; hotels; airlines; systems thinking/systems theory; market value.

Acknowledgment: The authors gratefully acknowledge the financial support (ECO0805487) provided by the Spanish Ministerio de Ciencia e Innovación.

\section{INTRODUCTION}

Corporate social responsibility (CSR) has expanded notably in recent years. Growing pressure from civil society actors and governmental initiatives has led firms to pay special attention to their social activities. While firms apply CSR principles voluntarily, some guidance or agenda must still exist so that firms know how to proceed. Accordingly, several norms attempt to provide a series of guidelines to implement CSR actions, such as the OECD Guidelines for Multinational Enterprises, the 10 principles of the United Nations Global Compact or the ISO 26000 Guidance Standard on Social Responsibility. In terms of governmental agendas, and by way of example, the European Commission has pioneered the promotion of CSR (e.g. the 2001 Green Paper) and in its 2011 plan it put forth a new definition of CSR as "the responsibility of enterprises for their impacts on society" (EC, 2011), establishing an action agenda for the period 2011-2014 with the general purpose of creating "conditions 
favorable to sustainable growth, responsible business behavior and durable employment generation in the medium and long term”.

Also, note that a firm's profit strategy pushes it to be socially responsible because of an anticipated benefit (e.g., reputation enhancement) from CSR actions (McWilliams and Siegel, 2000). In tourism, CSR initiatives have been shown to have a positive effect on firm performance (Nicolau, 2008), as sustainability is a crucial point in this industry (Lebe and Milfelner, 2006; Sheldon and Park, 2011; Whitfield et al, 2013). However, is this impact higher or lower than in other industries? More specifically, if we focus on hotels and airlines, do they show the same effect? Certainly, one of the most targeted marketing outcomes and, therefore, one of the main motivations for using CSR strategically is the opportunity it provides businesses to differentiate themselves from their competitors (Porter and Kramer, 2006) and to create a unique firm that may ultimately be more profitable (Lee, 2008). The exact contribution that a firm's CSR activities make to its performance as well as to its stakeholders should be accurately measured in order to be evaluated correctly. Some authors claims that the CSR approach is critical to managing the current crisis (Vizuete et al. 2013; Zizek and Mulej, 2013). Despite intensive research into the relationship between CSR and financial performance in recent decades, the results have been mixed (Peloza, 2009).

A possible explanation for these conflicting results is the misspecification of some industry-related factors (see Subsection 2.2 "Industry-specific CSR effects on firm performance and risk"). The development, disclosure and effects of CSR activities may vary according to industry type. In this article, stemming from the assumption that the relationship between a firm's CSR activities and its financial performance varies depending on the industry in which the firm is operating, we attempt to identify potential differentiated effects of CSR in the hotel and airlines industries, and to establish a ranking of CSR effects in terms of performance and risk. We use a market-based (rather than an accounting-based) measure as our proxy for financial performance, which allows us to overcome the prior studies' weaknesses associated with industry heterogeneity and measurement of this main variable. Essentially, our paper extends the existing literature on the relationship between CSR and firm performance and risk by analyzing how this relationship varies across different types of industries. To address these questions, we conduct an empirical analysis of data from the 248 firms that traded on the Spanish Stock Market between 1990 and 2007. The remainder of this paper is organized as follows: Section 2 presents our research hypotheses; Section 3 provides support for our proposed methodology and describes how we selected our sample and collected our data; Section 4 discusses our results; and Section 5 presents our conclusions.

\section{RESEARCH HYPOTHESES}

We begin this section with a discussion of the relationship between a given firm's CSR activities and its financial performance. We then introduce industry type (i.e., the industry to which the firm belongs) as a further determinant of this relationship in order to examine how CSR effects on firm performance can be industry specific. Finally, we consider how CSR effects on firm risk are likewise industry specific.

\subsection{Impact of CSR on Financial Performance}

As the incentives for a firm to implement social policies are increasingly economic in nature, the relationship between a firm's CSR activities and its financial performance has become one of the hottest topics in this stream of research (see, for example, the meta-analysis work by Ortlizky et al., (2003)). CSR can lead to direct and indirect benefits -internal and external- to the firm (Giz, 2012). Within the direct 
benefits, the internal ones include organizational commitment of employees, deeper talent pool (CSR attracts better applicants), operational effectiveness (CSR engagement leads to an internal change process); and the external direct benefits encompass reputation and publicity, and improved stakeholder relationships.

Regarding the indirect benefits, the internal ones include: i) Cost savings, as firms reduce several costs such as recruitment costs (as they have to invest less in attracting applicants), costs of worker turnover, costs of labor disputes and accidents, supervision costs (because of the increased organizational commitment of employees), advertisement costs (as proactive CSR activities induce publicity created by media), production costs derived from environment-oriented cost management, reduction in tax payments (there are some tax exemptions), after-sale costs (on account of quality improvements) and compliance costs (as CSR avoids government-imposed fines and increased insurance costs); ii) Innovation, as CSR activities tend to stimulate innovation; iii) Increased productivity, on account of the increase in efficiency in the use of resources; and iv) Improved quality, as the higher qualification of employees leads to better results both in terms of quantity and quality.

The indirect external benefits are: i) Better access to capital, on account of the firm's transparency; ii) Better market access for exporters and suppliers; iii) Customer satisfaction and price premium, because a good CSR reputation helps build reliable customer relations; iv) Risk reduction, because of improved stakeholder relations and avoidance of conflicts between firms, employees, communities and society; and v) Synergetic value creation derived from all the aforementioned factors, as the positive influence of CSR on the immediate environment improves the firm's competitive edge.

However, as many studies on this topic have highlighted, there are conflicting hypotheses about this relationship and a lack of consensus as to whether and how CSR activities affect a firm's financial outcomes (Park and Lee, 2009; Luo and Bhattacharya, 2006).

Some studies conclude that this relationship is either negative or at best inconclusive (e.g., Bromiley and Marcus, 1989; Moore, 2001). These studies argue that the additional costs that accompany large investments in CSR (Balabanis et al., 1998) could exceed the potential gains for shareholder wealth (Hull and Rothenberg, 2008). McWilliams and Siegel (2000, 2001), drawing on the supply-and-demand theory of the firm, also find evidence of a neutral relationship. Note that firms facing the dilemma over investing in CSR have to consider the potential opportunity costs implied: how much profit is the firm going to forego through investing in CSR rather than in other profitable activities (e.g. introducing a new product, reaching a new market segment, implementing a discount, etc.)? In a more formal way, opportunity costs in CSR include any activity that cannot be undertaken due to capital and labor being bound to the CSR activity, which might result in lost revenues (Sprinkle and Maines, 2010). Certainly, the effect of CSR activities on firm performance is disputed, as there might be fundamental tensions between commercial priorities and social, non-commercial activities. Nevertheless, the majority of studies find that the benefits associated with implementing CSR activities exceed the costs and therefore conclude that the relationship between a firm's CSR and its financial performance is positive. A firm perceived as highly socially responsible may face relatively fewer problems with its labor force and may find that its customers' positive attitude toward the firm makes them more favorably disposed to its products (Du et al., 2007; McDonald and Hung, 2011), and therefore more likely to purchase them. Barone et al. (2000), Berger and Kanetkar (1995) and Creyer and Ross (1997) all establish that consumers are willing to actively support firms 
committed to cause-related marketing, environmentally friendly practices, or ethics. Further, CSR activities might improve a firm's reputation (Vilanova et al., 2009) and relationship with its stakeholders, and these improved relationships may well translate into economic benefits (Bhattacharya and Sen 2004). What is more, according to Argandoña (2013), CSR can be seen as a cost-preventing strategy as it leads to a reduction in costs derived from litigation, complaints and fraud.

Therefore, according to Neville et al. (2005), an incomplete specification of the relationship between CSR and financial performance may be the cause of the mixed results cited above. Accordingly, a more detailed understanding of this relationship is in order.

In sum, the research on the topic has produced mixed empirical results, reporting that CSR activities have positive, negative and neutral impacts on a firm's performance. The lack of consensus has meant that the empiricists have not been able to resolve the theoreticians' dispute (Bird et al., 2007). Therefore, although there is no conclusive evidence on the direction of the relationship between CSR and financial performance, we hypothesize the following:

H1. A firm's CSR activities will positively affect its performance.

\subsection{Industry-specific CSR effects on firm performance and risk}

Industry effects may influence a firm's CSR initiatives and its performance (Michelon et al., 2012). In this line, previous studies suggest that the nature and level of CSR activity varies systematically across industries (Brammer and Pavelin, 2006; Godfrey et al., 2010; McWilliams et al., 2006). Adams and Hardwick (1998) find that the level of donations made by firms varies significantly across industries, and Melewar and Jenkins (2002) suggest that a firm's industry plays an important role in its ability to promote a corporate identity. Cowen et al. (1987) argue that consumer-oriented industries adopt social responsibility issues as part of their corporate image in hopes of influencing sales. Additionally, Jones (1999) suggests that among the industry-related factors that affect CSR activities are public visibility and the degree of governmental scrutiny to which some industries are subjected. He finds that primary sectors are more concerned with environmental issues; secondary sectors are more concerned with employees, suppliers, customers, the environment and communities; and service firms are more concerned with employees and consumers. As examples, the tobacco and alcoholic drinks industries are associated with highly visible social issues; the defence and pharmaceutical industries are carefully watched by ethical pressure groups; and the construction and resource extraction sectors are fully concerned with workplace health and safety (Brammer and Pavelin, 2006). Godfrey et al. (2010) find that "consumer service" industries focus heavily on community involvement, whereas business-tobusiness "heavy" industries focus not on communities but on the natural environment. Martinuzzi et al. (2010) conclude that CSR issues are highly industry, even subindustry, specific. They propose that CSR activities/measures could be evaluated more easily if they were in line with the industry agenda and contributed to solving industryspecific social and environmental problems. Taken together, these results indicate that the development and disclosure of CSR activities are likely a function of industry type.

Furthermore, a firm's financial performance is largely a function of the industry in which that firm is operating (Berrone et al., 2007). Each industry is subject to a unique set of circumstances, including governmental regulations, consumer orientation, and public visibility (Griffin and Mahon, 1997). For example, some industries lend 
themselves to higher levels of differentiation than others, and industry level factors would impact performance (McGahan and Porter, 1997). Godfrey et al. (2010) claim that industries vary in the types of materially important decisions they make, both economically (as different industries have different structures, production inputs and outputs, technologies and final products or services) and sociologically (as each industry is characterized by its own set of behaviors and competitive interactions), which in turn would affect firm performance. Specifically, numerous researchers suggest that a firm's industry must be included as a factor that affects the relationship between its CSR activities and its financial performance (McGahan and Porter, 1997; McWilliams and Siegel, 2000), and there is some evidence to suggest that the financial performance outcomes of responsible corporate behavior vary as a function of firm- and industry-specific factors (Simpson and Kohers, 2002). Therefore, controlling for industry-specific factors becomes critical if we are to empirically establish the relationship between CSR activities and financial performance with greater certainty.

Accordingly, we proceed on the assumption that individual industries operate within distinct contexts and with distinct social and environmental concerns (Chand and Fraser, 2006). Therefore, one would expect that shareholders make their decisions based on some heuristics that help them opt for buying or selling stocks. Here, the expectations of future cash-flows together with the risk implied are determinant (Ortas et al., 2013). However, with the plethora of information, how do they assess their options? According to Simon (1955), the human brain does not always try to obtain a rational solution to a problem by considering all the alternatives and optimizing, since it has a limited analytical capability. Hence, when confronted with a complex problem the "limited" human brain "satisfies" rather than optimizes (Kumar and Subramaniam, 1997). In this line, Steinbruner (2002) combined the notions of satisficing and models of cognitive processes to propose the "cybernetic" model of decision making. The "cybernetic" decision maker decomposes the problem and the environment into stable subsystems, within the framework of systems theory. The variety inherent in the decision problem is eliminated by ignoring it. Only a small set of critical variables are monitored and the final decision is made by a sequential process based on some heuristics. We, therefore, assume that shareholders base their investment decisions derived from CSR announcements on the idea that industries behave differently and that the fixed costs involved in each of them will have an effect on the impact of CSR actions on the firm's market value. Accordingly, the following two hypotheses will be based on this idea.

Observe that most of the previous literature on the relationship between CSR activities and financial performance focuses on cross-industry samples, which, according to Griffin and Mahon (1997), may yield results that mask individual differences that would otherwise allow us to measure corporate social and financial performance at the industry level. In sum, to understand the main effects of the relationship between CSR activities and firm performance, it is necessary to control for industry differences (e.g., Simpson and Kohers, 2002). Each industry's unique characteristics inform the relationship between CSR activities and firm performance, given that different industries face different portfolios of stakeholders with different levels of activity in different areas (Griffin and Mahon, 1997). Nevertheless, many studies on CSR fail to address key industry-specific issues, which confounds the process of making inter- and intra-firm comparisons that could otherwise be very interesting (Day and Woodward, 2009). Given the above, we hypothesize the following:

H2. The effect that a firm's CSR activities has on its market value will depend on the industry to which it belongs. 
In addition, it is conceivable that different CSR actions may lead to distinct changes in a firm's risk, depending on the amount of investment these initiatives involve and each industry's ratio of variable costs to fixed costs. Conceptually, it is possible to relate such CSR-driven variations in the firm's risk to changes in the firm's operating leverage via this ratio. A firm's operating leverage captures the sensitivity of its profits to changes in sales volume (Bernstein, 1993), such that highly leveraged (minimally leveraged) firms, once they reach the break-even point, will present substantial increases (decreases) in profits due to variations in turnover. This issue is especially relevant to firms who make investments that have high fixed costs, since the amount of these costs will cause that break-even point to vary. Therefore, we can formally express the final impact of an investment on the operating leverage as follows:

$$
O L=\frac{\partial P R}{\partial S} \frac{S}{P R}=\frac{\partial[S-v c \cdot S-F C]}{\partial S} \frac{S}{[S-v c \cdot S-F C]}=\frac{S-v c \cdot S}{S-v c \cdot S-F C},
$$

where $S$ is the sales volume, $P R$ is the firm's profits, $v c$ is the proportion of variable costs on sales and $F C$ the fixed costs.

The ultimate impact of the new investment will depend upon both the amount of fixed costs and the resultant increase in revenue. Intuitively, this new investment will decrease operating leverage if the following condition is satisfied:

$$
\frac{\frac{\Delta S}{S}}{\frac{\Delta F C}{F C}}>1 \text {, }
$$

where $\Delta S$ and $\triangle F C$ are the increase in sales and fixed costs, respectively.

Further, if we let $x$ be the amount of a given investment, we can take the derivatives to obtain

$$
\frac{\partial O L}{\partial x}=\frac{1-v c}{(S-v c \cdot S-F C)^{2}}\left\{\frac{\partial F C}{\partial x} S-\frac{\partial S}{\partial x} F C\right\} .
$$

Thus, a new investment will decrease operating leverage, $\partial O L / \partial x<0$, if it fulfils the following condition:

$$
\frac{\partial F C / F C}{\partial x}<\frac{\partial S / S}{\partial x},
$$

which coincides with the condition stated before. Therefore, an investment's ultimate impact on the investing firm's operating leverage, and consequently on the firm's sensitivity, depends on the size of the relative variation in both sales volume and fixed costs. As the effects that CSR activities have on these figures are contingent upon the characteristics of the industry to which the investing firms belong, we further hypothesize the following:

H3. The effects that a firm's CSR activities have on its risk will vary as a function of the industry to which that firm belongs.

\section{METHOD}

\subsection{The event-study technique}

We base our analysis on the event-study technique and assume that stock markets are efficient and that a firm's share price reflects its CSR strategy. Any information that the market receives about a firm (e.g., via the firm's CSR activities) will be instantly 
incorporated into the firm's share price. The event-study method enables us to estimate the excess returns generated by a sample of unanticipated events, in our case, announcements of CSR activities. The method's underlying assumption is that abnormal returns reflect stock market reactions to the arrival of new information. The event study measures the impact of unanticipated events on share prices by estimating a market model for each event and then calculating the associated abnormal returns.

\subsection{Data collection}

To collect our data, we follow the event-study technique, which draws on the data collection process presented in McWilliams and Siegel (1997). We begin, in the first stage, with our sample of the 248 firms that traded on the Spanish Stock Market between 1990 and 2007. As we rely on firm market value (the "stock market price" multiplied by the "number of shares") -rather than on a firm's accounting books- to measure the effect of CSR on firm performance, we assume that stock prices represent all the information available in the market and these prices will change depending on the positive and negative information. However, the inception of the current crisis made the stock exchanges around the world be alert to any kind of crisis-related news; actually, starting in January 2008 and especially after October 2008, the stock exchanges plummeted in such a way that any news announcements were no longer paid attention to in the same way, as priorities changed. What is more, including CSR-related news of this crisis period (after 2007) would lead to defective estimates and the reactions in stock markets would not be properly reflecting the firm-specific information, but the general macroeconomic situation. Using the Factiva databasewhich supplies information on headlines and news items published in different newspapers of national and international coverage, as well as of general or specialized content-we identify the sample firms that conducted CSR activities. Specifically, we conducted a search of the Factiva database by pairing the name of each firm with key words such as "CSR," "social action”, "philanthropy”, "sustainability”, "good corporate governance”, “informative transparency”, “disable”, “ethics”, “technological innovation", "sponsorship", "environment" and other variants. When the result of a search was unclear, we consulted the full news item in the corresponding newspaper. Ultimately, we reviewed around 28,300 news items, and identified 2,246 CSR initiatives. We defined the event day as the first day in which any one of the publications listed on the database divulged the news.

In the second stage, we test for any abnormal behavior in the returns on firm shares within our event window, whose length $k$ we set to five days before and five days after (i.e., $-5 ;+5)$ the announcement date. We chose this window because, although we expect that the majority of information related to CSR activities will be quickly incorporated into the share prices, on occasion information either leaks out before it is formally published or is held back for some reason.

In the third stage, we eliminate announcements of CSR actions from the same firm that were issued very close in time to one another within the 5-day event window as it would not be possible to determine which of them, if any, was generating abnormal returns. This process reduces our sample to 1,394 announcements.

In the fourth stage, we discard any announcements whose event windows also include key words such as "takeover bid", "share offer", "profit announcement", "dividend declarations”, "split”, “complaints”, “claims”, “quality”, “trade union”, "mergers”, "labor disputes”, “dismissals”, "government contracts”, “court cases”, "introduction of new products" and other related terms. This process helps to ensure that we are measuring only the effect of the CSR action, and not that of other factors. 
This process further reduces our sample to 583 announcements. These remaining announcements contain the following key words from our original search: "environmental issues", "responsible labor relationships", "social action”, "good corporate governance”, "informative transparency", "sponsorship” and "technological innovation." We wish to stress here that our data collection process guarantees that all of these news items were released during our study period.

In the fifth stage, we collect data on market measures of performance, which allows us to consider the amount of risk the firm is carrying and the capitalized value (i.e., the expectations) of the benefits to be derived from the CSR activities, as well as to minimize any distortions arising from tax laws and accounting standards. We adjust these daily returns with dividends, subscription rights, and splits. We express the returns on the share price of firm $i$ on day $t\left(R_{i t}\right)$ as:

$$
R_{i t}=\alpha_{i}+\beta_{i} R_{m t}+\varepsilon_{i t}(1)
$$

where $R_{m t}$ captures the returns on the market portfolio on day $t$ (we obtain our information from the Stock Exchange Society, and use, as a substitute variable for the true returns on the market, the IBEX-35, a representative index of the Spanish Stock Market); $\alpha_{i}$ captures the returns on the shares of firm $i$ independent of those of the market; $\beta_{i}$ is the sensitivity of the returns on firm $i$ shares to variations in market returns; and $\varepsilon_{i t}$ is an error term. The estimation of equation (1) allows us to calculate daily abnormal returns (AR) for each announcement of firm $i$ :

$$
A R_{i t}=R_{i t}-\left(a_{i}+b_{i} R_{m t}\right)(2) \text {, }
$$

where $a_{i}$ and $b_{i}$ are the estimations of regression (1) for a period $T$ before the event. We recognize the characteristic kurtosis and heteroskedasticity present in the error term of equation (1), and consequently estimate an autoregressive conditional heteroskedasticity model, GARCH(1,1), in order to model the conditional variance of the returns. Such models distinguish between unconditional variance, which is constant and stationary, and conditional variance, which is modified by the available information. We obtain the returns thereby defined by assuming that

$$
\begin{gathered}
\varepsilon_{i t}=h_{i t}{ }^{1 / 2} \eta_{i t}, \text { and } \\
\varepsilon_{i t} / \varepsilon_{i t-1}, \varepsilon_{i t-2}, \ldots \sim \mathrm{N}\left(0, h_{i t}\right),
\end{gathered}
$$

where $\eta_{i t}$ i.i.d. with $\mathrm{E}\left(\eta_{i t}\right)=0$ and $\mathrm{E}\left(\eta_{i t}^{2}\right)=1$. In this context, $h_{i t}$ is the conditional variance and is represented as

$$
h_{i t}=c_{i}+\lambda_{i} \varepsilon_{i t-1}^{2}+\gamma_{i} h_{i t-1},
$$

where $c_{i}, \lambda_{i}$, and $\gamma_{i}$ are the parameters to be estimated.

\subsection{Testing abnormal returns}

Abnormal returns are the returns a firm receives once investors have adjusted them for normal returns; in other words, investors adjust the return on shares by subtracting the expected returns from the actual returns, and any significant difference between the two is considered abnormal. To analyze the effect of the announcement of a firm's CSR activities on its share price, we test the significance of the average abnormal returns for the announcements of $N$ firms on the event day $(t=0)$ using the traditional parametric test presented in Brown and Warner's (1980) and the parametric test presented in Boehmer et al. (1991), which takes into account event-induced variance changes. In addition, we analyze changes in a firm's risk using two tests: i) a test that compares the number of shares with an increase in post-event and pre-event volatility; and ii) a test that determines whether the ratio of post-event volatility to pre-event volatility is significantly greater than 1 . 


\section{RESULTS}

The results demonstrate that, on average, announcements of CSR activities are associated with positive excess returns on the days after the event: for the event window $(+1,+5)$ we obtain significant abnormal returns of $0.26 \%$ [Brown and Warner test $=2.01$ $(\mathrm{p}<0.05)$ and Boehmer et al test=2.03 $(\mathrm{p}<0.05)]$, for the window $(+2,+5): 0.24 \%[2.07$ $(\mathrm{p}<0.05)$ and $1.88(\mathrm{p}<0.1)]$; for the window $(+3,+5): 0.18 \%[2.13(\mathrm{p}<0.05)$ and 1.90 $(\mathrm{p}<0.1)]$; and for the window $(+4,+5): 0.21 \%$ [2.55 $(\mathrm{p}<0.05)$ and $2.40(\mathrm{p}<0.05)]$. This finding provides support for our first hypothesis (H1), which positively links CSR activities and firm performance. These results are in line with, among others, Barone, Miyazaki and Taylor (2000) and Du, Bhattacharya and Sen (2007), who attribute this positive effect to consumers' positive attitudes and their predisposition toward purchasing products from firms that invest in CSR, which, in turn, have higher expectations of making sales. Indeed, McDonald and Hung (2011) find that consumers' positive attitudes are strong determinants of positive consumer behavior in response to CSR initiatives. Accordingly, managers could utilize customer-centric initiatives, to which consumers are more sensitive, as a strategy for boosting customers' attitudes and positive behavior and attracting more customers, and thereby to increase their financial performance. Therefore, as stated in Nicolau (2008), firms' socially oriented activities benefit society both directly (i.e., through the inherent purpose of such activities) and indirectly (i.e., through the firms' commercial performance).

Additionally, we test for whether CSR activities involve different levels of investment and different ratios of variable to fixed costs in each industry. To this end, we focus on changes in volatility and find that $55 \%$ of shares exhibit increased volatility after the event $(p<0.009)$. Moreover, the average ratio of post-event volatility to preevent volatility is 1.1503 or a $15 \%$ increase in risk, which is significantly different from one $(t=2,575 ; p<0.01)$. The empirical results show that $P\left(\bar{R}_{2}^{2}>\bar{R}_{1}^{2}\right)=0.5446$. Thus, assuming that

$$
\bar{R}_{1} \sim N\left(0, \sigma_{1}^{2}\right) \text { у } \bar{R}_{2} \sim N\left(0, \sigma_{2}^{2}\right)
$$

and being

$$
\operatorname{Cov}\left(\bar{R}_{1}^{2}, \bar{R}_{2}^{2}\right)=0
$$

it holds that

$$
S=\frac{\bar{R}_{2}^{2} / \sigma_{2}^{2}}{\bar{R}_{1}^{2} / \sigma_{1}^{2}} \sim F_{1,1}
$$

Therefore, the variation can be easily obtained through the equation

$$
\begin{gathered}
P\left(\bar{R}_{2}^{2}>\bar{R}_{1}^{2}\right)=P\left(S>\sigma_{1}^{2} / \sigma_{2}^{2}\right), \\
\text { as } P\left(S>\sigma_{1}^{2} / \sigma_{2}^{2}\right)=1-0.5446=0.4554 .
\end{gathered}
$$

Consequently, the value of $\sqrt{E\left(\bar{R}_{2}^{2}\right) / E\left(\bar{R}_{1}^{2}\right)}$ can be estimated by finding the value of the inverse of $\sigma_{1}^{2} / \sigma_{2}^{2}$ in the distributional tables. In this case, the value is 1.1509, which is quite similar to the volatility ratio (1.1503). 
Ultimately, we find that the post-event volatility increases, which suggests that shareholders expect the firm to be less protected against risk; or, to put it another way, that the fixed costs required to make the investment exceed the future sales expectations as a result of that investment. Recall that at this point there are two competing forces at play: on the one hand, increased expectations of sales based on consumer's positive attitudes and greater predisposition toward buying the firm's products, and, on the other hand, increased expectations of the costs incurred to maintain CSR activities in the long term.

\section{[Table 1 about here]}

As we state in Hypotheses 2 and 3, the industry to which a firm belongs must be included as a factor in that firm's performance and risk. To test these hypotheses, we first calculate the abnormal returns and the volatility ratio for each industry and then test for differences between them. Table 1 presents the average abnormal returns, volatility ratios and the ratio between abnormal returns and volatility of the 583 CSR announcements when the industry effects are included, and Table 2 presents the results of the Kruskal Wallis test and the Median test for both abnormal returns and volatility ratio, which allow us to statistically compare these values across industries. Analyzing these significant differences at the industry level allows us to account for industry idiosyncrasy when evaluating some consequences of the CSR activities. Our findings are in line with those of Melo and Garrido-Morgado (2012), who also find that CSR activities have a significant impact on a firm's reputation, moderated by the firm's industry, which in turn is positively (negatively) affected by financial performance (risk) (Brammer and Pavelin, 2006).

\section{[Table 2 about here]}

Specifically, Hypothesis 2 suggests that while a firm's CSR activities will impact their market values, the extent and type of this influence will vary depending on the industry in which the firm is operating. We test this hypothesis using the Kruskal Wallis and the Median tests, which, at $0.05 \%$ and $0.1 \%$, respectively, both yield a statistically significant value for the difference between the returns in different sectors, and confirm the intuition that industry-level factors will affect the returns that CSR activities generate. Figure 1 illustrates important differences in abnormal returns as a function of the industry to which the firm belongs. Specifically, firms in the air transportation industry (45) have the most negative abnormal returns after their CSR announcements. Firms in other industries, such as textiles (22), tobacco products (21), electronic and other electric equipment and components (36) and apparel and accessory stores (56) also experience negative excess returns in the days after the announcement of their CSR activities. Firms in the wholesale trade-durable goods industry (50), on the other hand, show the highest corporate performance, as represented by their market value. Other industries where firms' CSR announcements have remarkably positive effects on performance include holding and other investment offices (67) and business services (73).

\section{[Figure 1 about here]}

Regarding the variation in risk by industry, Table 2 displays results that support our third hypothesis, namely, that the effects that a firm's CSR activities have on its risk will vary as a function of the industry to which it belongs. Figure 2, which displays differences in volatility ratios across industries, illustrates how industry heterogeneity affects risk variation. Specifically, firms in the air transportation industry (45) show the 
highest risk after their CSR announcements. Firms in other industries, such as transportation equipment (37), depository institutions (60) and engineering, accounting, research, management and related services (87), also display high volatility ratios on the days after the announcement of their CSR activities.

Therefore, while the hotel industry presents an average behavior (standing at 9th position in performance, 15th in terms of risk and 8th according to the ratio returns/volatility), the airline industry presents the worst situation of all industries: last in performance and last in risk (if we consider both returns and volatility simultaneously, the situation ameliorates a little).

\section{CONCLUSIONS}

\section{[Figure 1 about here]}

In recent years, CSR has claimed its place as a new model for business management, and more and more firms are including it as part of their overall strategy. Accordingly, most firms regard CSR as a strategy option that management can use to improve economic output. In this paper, we address this important topic-namely, how a firm's CSR activities affect its value-through an industry-level analysis that aims to identify differences in performance and risk across industries.

We proceed by examining whether a firm's CSR activities affect its market value. Specifically, we predict that a firm's CSR activities will have a positive impact on its risk and performance, and that these effects will vary as a function of the industry in which the firm is operating. We test these hypotheses using an event study of the 583 announcements of CSR activities made by our sample of 248 firms that traded on the Spanish Stock Market between 1990 and 2007.

We find that, on average, when we test this relationship without including industry-level factors, CSR announcements are associated with positive excess returns on the post-event days. However, we also demonstrate that a firm's industry must be included as a factor affecting the relationship between a firm's announcements of CSR activities and its performance and risk. Indeed, when we compare the abnormal returns and volatility ratios that derive from CSR activities at the industry level, we find that these values vary significantly: while the hotel industry presents an average behavior, the airline industry presents the worst situation: last in performance and last in risk.

Our results have critical implications for managers who wish to know how the CSR activities they have planned will impact the economic value of their firm. Based on our finding that CSR activities are not valued equally in all industries, managers can more efficiently allocate firm resources to their CSR strategy, taking into account, among other factors, the industrial sector in which the firm is operating. By regarding their investment in CSR activities as part of a suitable corporate strategy from both an ethical and an economic perspective, given that such activities can improve a firm's image (Prado-Lorenzo, et al., 2008), managers can obtain competitive advantages and reap greater financial benefits (Luo and Battacharya, 2006).

Three further avenues of research stand out: 1) In line with the analysis by Nicolau and Sellers (2002) for the ISO 9000, it would be relevant to analyze the effect of the ISO 26000 on firm value. Note that, contrary to the ISO 9000 and ISO14000, the ISO 26000 is not a certificate per se but a set of guidelines, so the event to be analyzed is not the time "a certificate has been granted" but the time "a firm announces that it is going to adhere to the ISO 26000 principles". 2) Given that the ISO 26000 includes seven categories of activities (organizational governance, human rights, labor practices, 
the environment, fair operating practices, consumer issues and community involvement and development), it could be useful to know which action brings about a greater impact on firm value. What is more, several dimensions could be proposed as explanatory variables for the potential abnormal returns, if any, derived from each type of activity. 3) In an analogous way to Nicolau and Sellers (2010) and their analysis of the different effects that distinct types of quality certificates can have on firm performance, it would provide managers with a useful tool if a study analyzed the impacts of the different CSR criteria that exist today, such as the ISO 26000, the OECD Guidelines for Multinational Enterprises, the 10 principles of the UN Global Compact, the UN Guiding Principles on Business and Human Rights or the ILO Tripartite Declaration of Principles on Multinational Enterprises and Social Policy. If discrepancies in results were to exist, managers would know which guidelines are more appropriate to follow or, at least, which guidelines are more visible and more accepted by the market.

\section{REFERENCES}

Adams, M., and P. Hardwick (1998), “An analysis of corporate donations: United Kingdom evidence”, Journal of Management Studies, 35 (5), 641-654.

Argandoña, A. (2013), "Why should managers be socially responsible?”, The European Business Review, p.1, http://www.europeanbusinessreview.com/?p=8408

Balabanis, G., H.C. Phillips, and J. Lyall (1998), "Corporate social responsibility and economic performance in the top British companies: are they linked?”, European Business Review, 98(1): 25-44.

Barone, M.J., A.D. Miyazaki, and K.A. Taylor (2000), "The influence of cause related marketing on consumer choice does one good turn deserve another?", Journal of the Academy of Marketing Science, 28 (2): 248-262.

Berger, I.E., and V. Kanetkar (1995), "Increasing environmental sensitivity via workplace experiments”, Journal of Public Policy and Marketing, 14(2): 205-215.

Bernstein, L.A. (1993), Analysis of Financial Statements, Homewood: Irwin.

Berrone, P., J. Surroca, and J.A. Tribó (2007), “Corporate ethical identity as a determinant of firm performance: a test of the mediating role of stakeholder satisfaction”, Journal of Business Ethics, 76: 35-53.

Bhattacharya C. and S. Sen (2004), "Doing better at doing good: When, why and how consumers respond to corporate social initiatives" California Management Review 47(1): 9-25.

Bird, R., A.D. Hall, F. Momentè, and F. Reggiani (2007), "What corporate social responsibility activities are valued by the market?”, Journal of Business Ethics 76: 189206.

Boehmer, E., J. Masumeci, and A.B. Poulsen (1991), "Event-study methodology under conditions of event-induced variance," Journal of Financial Economics, 30(2): 253272.

Brammer, S.J., and S. Pavelin (2006), "Corporate reputation and social performance: the importance of fit”, Journal of Management Studies, 43 (3), 435-455.

Bromiley, P. and A. Marcus (1989), "The deterrent to dubious corporate behavior: profitability, probability, and safety recalls”, Strategic Management Journal, 10: 233250. 
Brown, S., and J.B. Warner (1980), “Measuring security price performance,” Journal of Financial Economics, 8: 205-258.

Chand, M. and S. Fraser (2006), "The relationship between corporate social performance and corporate financial performance: industry type as a boundary condition”, The Business Review, Vol. 5(1): 240-245.

Cowen, Scott S.; Ferreri, Linda B.; and Parker, Lee D. (1987), "The impact of corporate characteristics on social responsibility disclosure: a typology and frequency-based analysis”, Accounting, Organizations and Society, 12 (2), 111-122.

Creyer, E.H., and W.T. Ross (1997), "The influence of firm behavior on purchase intention: do consumers really care about business ethics?", Journal of Consumer Marketing, 14(6): $421-432$

Day, R., and T. Woodward (2009), "CSR reporting and the UK financial services sector”, Journal of Applied Accounting Research, 10 (3), 159-175.

Du, S., C.B. Bhattacharya, and S. Sen (2007), "Reaping relational rewards from corporate social responsibility: the role of competitive positioning”, International Journal of Research in Marketing, 24(3): 224-241.

European Commission (2011), "Communication from the Commission to the European Parliament, the Council, the European Economic and Social Committee and the Committee of the Regions: A renewed EU strategy 2011-14 for Corporate Social Responsibility”, lex.europa.eu/LexUriServ/LexUriServ.do?uri=COM:2011:0681:FIN:EN:PDF

GIZ, German Society for International Cooperation (2012),"Costs and Benefits of Corporate Social Responsibility (CSR)", Sino-German Corporate Social Responsibility Project, report http:/www.chinacsrproject.org/Uploads/\%7BEA74A6EC-FCD4-4699-B0EDFE83A70F854D\%7D_Costs\%20and\%20Benefits\%20of\%20CSR_20120615.pdf

Godfrey, P.C., N.W. Hatch, and J.M. Hansen (2010), “Toward a general theory of CSRs: The roles of beneficence, profitability, insurance, and industry heterogeneity”, Business \& Society, 49(2): 316-344.

Griffin, J.J., and J.F. Mahon (1997), "The corporate social performance and corporate financial performance debate: twenty-five years of incomparable research”, Business and Society, 36 (1): 5-31.

Hull, C. E., and S. Rothenberg (2008), "Firm performance: The interactions of corporate social performance with innovation and industry differentiation”, Strategic Management Journal, 29: 781-789.

Jones, M.T. (1999), “The institutional determinants of social responsibility", Journal of Business Ethics 20: 163-179.

Klein, J., and N. Dawar (2004), "Corporate social responsibility and consumers' attributions and brand evaluations in a product-harm crisis”, International Journal of Research in Marketing, 21: 203-217.

Kumar, V. and V. Subramaniam (1997), “A Contingency Framework for the Mode of Entry Decision”, Journal of World Business, 32, spring, 53-72.

Lebe, S.S. and Milfelner, B. (2006) "Innovative organisation approach to sustainable tourism development in rural areas", Kybernetes, Vol. 35 Iss: 7/8, pp.1136 - 1146. 
Lee, M.P. (2008), "A review of the theories of corporate social responsibility: Its evolutionary path and the road ahead." International Journal of Management Reviews, 10(1): 53-73.

Luo, X., and C.B. Bhattacharya (2006), "Corporate social responsibility, customer satisfaction, and market value”, Journal of Marketing, 70(October): 1-18.

Martinuzzi, A., S. Gisch-Bole, and A. Wiman (2010), "Does corporate responsibility pay off? Exploring the links between CSR and competitiveness in Europe's industrial sectors”, Research Institute for Managing Sustainability (RIMAS), Vienna University of Economics and Business, November 2010.

McDonald, L.M., and L.C. Hung (2011), "Impact of corporate social responsibility initiatives on Taiwanese banking customers," International Journal of Bank Marketing, 29(1): 50-63.

McGahan, A.M., and M.E. Porter (1997), "How much does industry matter, really?”, Strategic Management Journal, Summer Special Issue, 18 (S1), 15-30.

McWilliams, A., and D. Siegel (1997), "Events studies in management research: theoretical and empirical issues," Academy of Management Journal, 40(3): 568-592.

McWilliams, A., and D. Siegel (2000), "Corporate social responsibility and financial performance: correlation or misspecification?”, Strategic Management Journal, 21 (5), 603-609.

McWilliams, A., and D. Siegel (2001), "Corporate social responsibility: A theory of the firm perspective”, Academy of Management Review, 26: 117-127.

McWilliams, A., D. Siegel, and P. Wright (2006), "Corporate social responsibility: strategic implications”, Journal of Management Studies, Vol. 43(1): 1-18.

Melewar, T.C., and E. Jenkins (2002), "Defining the corporate identity construct", Corporate Reputation Review, 5 (1), 76-90.

Melo, T. and A. Garrido-Morgado (2012), "Corporate reputation: A combination of social responsibility and industry”, Corporate Social Responsibility and Environmental Management, 19: 11-31.

Michelon, G., G. Boesso, and K. Kumar (2012), "Examining the link between strategic corporate social responsibility and company performance: an analysis of the best corporate citizens", Corporate Social Responsibility \& Environmental Management, DOI: $10.1002 /$ csr.1278

Moore, G. (2001), "Corporate social and financial performance: an investigation in the UK supermarket industry”, Journal of Business Ethics, 34(3/4): 299-315.

Neville B., S. Bell, and B. Menguc (2005), "Corporate responsibility, stakeholders and the social performance - financial performance relationship”, European Journal of Marketing, 39(9/10): 1184-98.

Nicolau, J.L. (2008), “Corporate social responsibility: worth-creating activities”, Annals of Tourism Research, 35 (4), 990-1006.

Nicolau, J.L. y Sellers, R. (2002) “The Stock Market's Reaction to Quality Certification: Empirical Analysis from Spain”, European Journal of Operational Research, 142 (3), 632-641.

Nicolau, J.L. y Sellers, R. (2010) "The quality of quality awards: Diminishing information asymmetries in a hotel chain", Journal of Business Research, 63, 8, 832-839. 
Ortas, E., Moneva, J.M and Salvador, M. (2013) "Do social and environmental screens influence ethical portfolio performance? Evidence from Europe”, Cuadernos de Economía y Dirección de la Empresa, forthcoming

Park S., and S. Lee (2009), "Financial rewards for social responsibility", Cornell Hospitality Quarterly, 50(2): 168-79.

Peloza, J. (2009), "The challenge of measuring financial impacts from investments in corporate social performance”, Journal of Management, 35(6): 1518-1541.

Porter, M.E., and M.R. Kramer (2006), "Strategy \& society: the link between competitive advantage and corporate social responsibility." Harvard Business Review, 84(12): 7892.

Sen, S., Bhattacharya, C.B. (2004), "Doing better at doing good: When, why, and how consumers respond to corporate social initiatives", California Management Review, 47(1): 9-24.

Sen, S., C.B. Bhattacharya, and D. Korshun (2006), "The role of corporate social responsibility in strengthening multiple stakeholder relationships: a field experiment”, Journal of the Academy of Marketing Science, 34: 158-166.

Sheldon, P.J. and Park, S.Y. (2011) “An Exploratory Study of Corporate Social Responsibility in the U.S. Travel Industry”, Journal of Travel Research, 50, 4, 392407.

Simon, H. (1955). “A behavioural model of rational choice.” Quarterly Journal of Economics, 69: 99-118.

Simpson, W.G., and T. Kohers (2002), "The link between corporate social and financial performance: evidence from the banking industry”, Journal of Business Ethics, 35, 97-102.

Sprinkle, G. B., \& Maines, L. A. (2010). The benefits and costs of corporate social responsibility. Business Horizons , 53, S. 445-453.

Steinbruner, J. (2002). The cybernetic theory of decision. Princeton: Princeton University Press.

Vilanova, M., J.M. Lozano, and D. Arenas (2009), "Exploring the nature of the relationship between CSR and competitiveness”, Journal of Business Ethics, 87: 5769.

Vizuet, E., Gil-Lafuente, A.M., García, A. and Boria-Reverter, S. (2013) "Forgotten effects of corporate social and environmental responsibility: A case study of Catalonian economy", Kybernetes, Vol. 42 Iss: 5, pp.736 - 753.

Whitfield, J. and Dioki, L.A.N. (2012) "Measuring and Examining the Relevance of Discretionary Corporate Social Responsibility in Tourism: Some Preliminary Evidence from the U.K. Conference Sector", Journal of Travel Research, 51, 3, 289-302.

Žižek, S.S. and Mulej, M. (2013) "Social responsibility: a way of requisite holism of humans and their well-being", Kybernetes, Vol. 42 Iss: 2, pp.318 - 335. 
Table 1. Rankings based on abnormal returns and volatility change by industry (SIC codes in brackets)

\begin{tabular}{|c|c|c|c|c|c|c|}
\hline Industry & $\begin{array}{l}\text { Abnormal returns } \\
\text { (AR) }\end{array}$ & $\begin{array}{l}\text { Volatility ratio } \\
\text { (V) }\end{array}$ & $\mathrm{AR} / \mathrm{V}$ & $\begin{array}{l}\text { Ranking by } \\
\text { AR }\end{array}$ & $\begin{array}{l}\text { Ranking by } \\
\text { V }\end{array}$ & $\begin{array}{l}\text { Ranking } \\
\text { by AR/V }\end{array}$ \\
\hline Wholesale trade-durable goods (50) & 0.0195 & 1.001 & 0.0195 & 1 & 21 & 1 \\
\hline Holding and other investment offices (67) & 0.0149 & 0.831 & 0.0179 & 2 & 28 & 2 \\
\hline Business services (73) & 0.012 & 0.801 & 0.0150 & 3 & 29 & 3 \\
\hline Stone, clay, glass, and concrete products (32) & 0.0095 & 1.054 & 0.0090 & 4 & 14 & 4 \\
\hline Apparel and other finished products made from fabrics (23) & 0.0092 & 1.149 & 0.0080 & 5 & 8 & 5 \\
\hline Insurance, carriers (63) & 0.0055 & 1.002 & 0.0055 & 7 & 20 & 6 \\
\hline Eating and drinking places (58) & 0.0053 & 1.246 & 0.0043 & 8 & 6 & 7 \\
\hline Hotels, rooming houses, camps, and other lodging places (70) & 0.0043 & 1.054 & 0.0041 & 9 & 15 & 8 \\
\hline $\begin{array}{l}\text { Engineering, accounting, research, management, and related } \\
\text { services(87) }\end{array}$ & 0.0069 & 1.769 & 0.0039 & 6 & 2 & 9 \\
\hline $\begin{array}{l}\text { Local and suburban transit and interurban highway passenger traffic } \\
\text { (41) }\end{array}$ & 0.004 & 1.048 & 0.0038 & 10 & 17 & 10 \\
\hline Construction-special trade contractors (17) & 0.0021 & 0.564 & 0.0037 & 13 & 30 & 11 \\
\hline Paper and allied products (26) & 0.003 & 1.065 & 0.0028 & 12 & 13 & 12 \\
\hline Food stores (54) & 0.0019 & 0.846 & 0.0022 & 14 & 27 & 13 \\
\hline Depository institutions (60) & 0.0037 & 1.723 & 0.0021 & 11 & 3 & 14 \\
\hline Electric, gas, and sanitary services (49) & 0.0015 & 1.135 & 0.0013 & 15 & 10 & 15 \\
\hline Primary metal industries (33) & -0.0001 & 0.93 & -0.0001 & 16 & 24 & 16 \\
\hline Communications (48) & -0.0002 & 1.117 & -0.0002 & 17 & 11 & 17 \\
\hline Food and kindred products (20) & -0.0008 & 1.052 & -0.0008 & 18 & 16 & 18 \\
\hline Petroleum refining (29) & -0.0014 & 0.99 & -0.0014 & 19 & 22 & 19 \\
\hline Building construction (15) & -0.0015 & 1.018 & -0.0015 & 20 & 19 & 20 \\
\hline Oil and gas extraction (13) & -0.0018 & 1.136 & -0.0016 & 21 & 9 & 21 \\
\hline Chemicals and allied products (28) & -0.0025 & 1.092 & -0.0023 & 23 & 12 & 22 \\
\hline Industrial and commercial machinery and computer equipment (35) & -0.0023 & 0.864 & -0.0027 & 22 & 26 & 23 \\
\hline Transportation equipment (37) & -0.0064 & 1.581 & -0.0040 & 24 & 4 & 24 \\
\hline Heavy construction (16) & -0.0075 & 1.245 & -0.0060 & 25 & 7 & 25 \\
\hline Apparel and accessory stores (56) & -0.0119 & 1.33 & -0.0089 & 27 & 5 & 26 \\
\hline Transportation by air (45) & -0.0309 & 2.642 & -0.0117 & 30 & 1 & 27 \\
\hline Tobacco products (21) & -0.0117 & 0.903 & -0.0130 & 26 & 25 & 28 \\
\hline Textile mill products (22) & -0.0154 & 1.02 & -0.0151 & 28 & 18 & 29 \\
\hline Electronic and other electric equipment and components (36) & -0.0206 & 0.978 & -0.0211 & 29 & 23 & 30 \\
\hline
\end{tabular}


Table 2. Tests for differences in abnormal returns and volatility ratio by industry

\begin{tabular}{lcc}
\hline & Abnormal returns & Volatility \\
\hline $\begin{array}{l}\text { Kruskal Wallis } \\
\text { test }\end{array}$ & $50.83^{\mathrm{a}}$ & $46.53^{\mathrm{b}}$ \\
Median test & $48.52^{\mathrm{b}}$ & $46.67^{\mathrm{b}}$ \\
\hline Note: ${ }^{\mathrm{a}} p<.05 ;{ }^{\mathrm{b}} p<.1$ & &
\end{tabular}

Note: ${ }^{\mathrm{a}} p<.05 ;{ }^{\mathrm{b}} p<.1$ 
Figure 1. Graphical abnormal return differences by industry

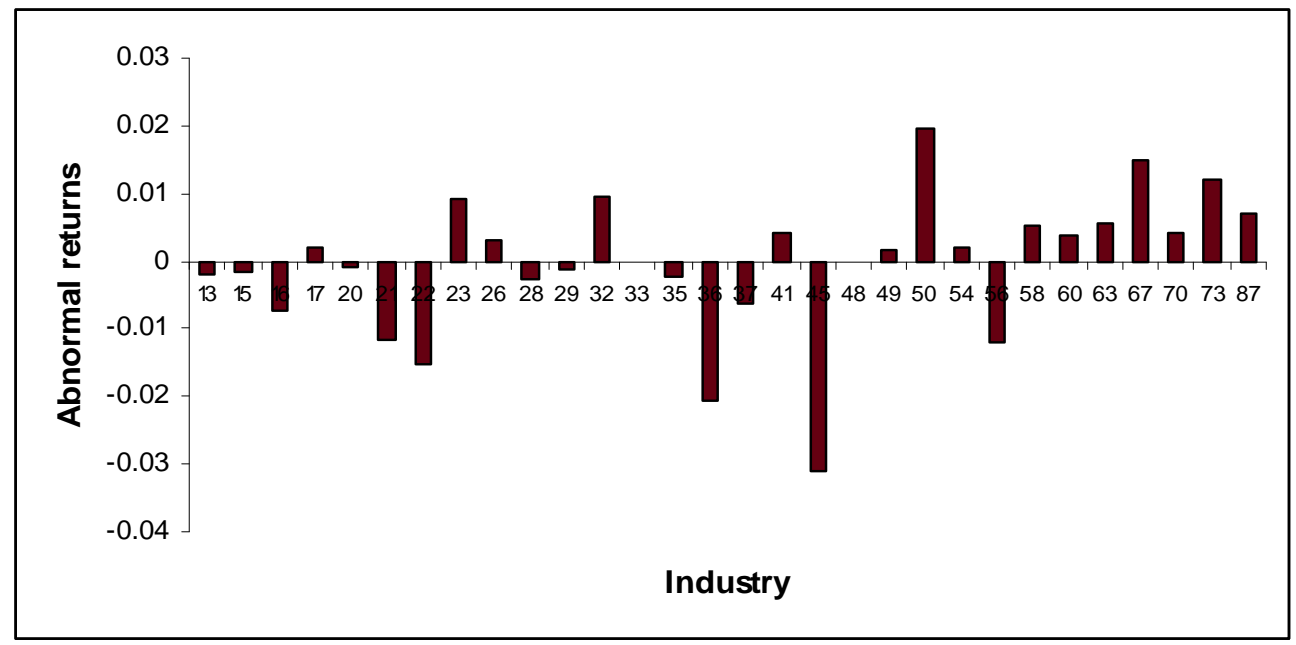


Figure 2. Graphical volatility ratio differences by industry

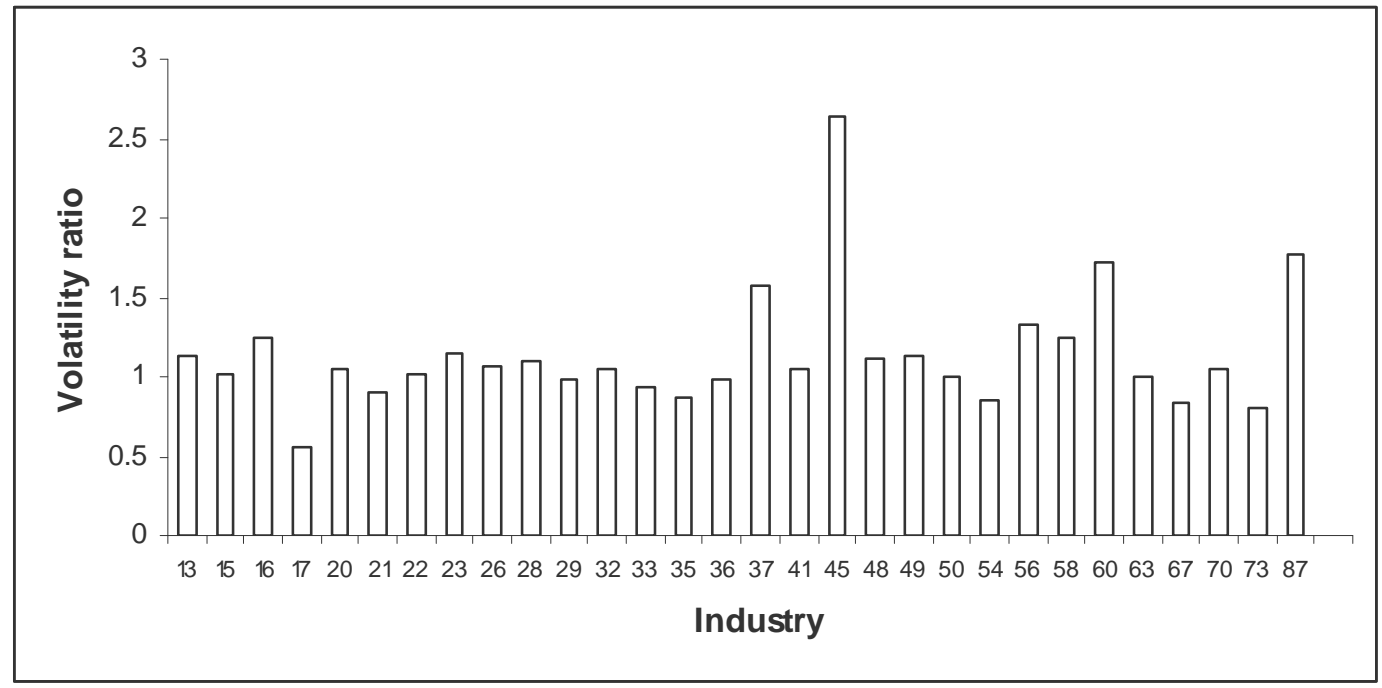

